\title{
EI martirio de san Lorenzo frente a la Reforma. Caso paradigmático de cristianización del espacio pagano y defensa ante las acusaciones de idolatría
}

\section{The martyrdom of Saint Lawrence and the Reformation. A paradigmatic case of Christianisation of a pagan territory and a defense against the accusations of idolatry}

\author{
Juan Mauro Bozzano \\ Universidad de Alcalá de Henares
}

Fecha de recepción: 26 de febrero de 2020

Fecha de aceptación: 29 de mayo de 2020

\section{RESUMEN}

En su Liber Peristephanon, Prudencio promueve la cristianización del espacio a través del culto a los santos y la veneración de sus reliquias. El poeta y Padre de la Iglesia se inscribe de esta forma en el esfuerzo de los cristianos del siglo IV para apropiarse del territorio imperial a través la construcción de una red de lugares santos. Por otra parte, una lectura detallada de este texto nos permite deducir que sería la resistencia pasiva de los mártires, y sobre todo aquella de san Lorenzo, la que habría terminado con el reino de los dioses paganos en Roma y en su Imperio. La influencia del texto de Prudencio ha llevado a Tiziano -y, luego, a otros artistas- a introducir en sus representaciones del martirio de san Lorenzo un mensaje que destaca la oposición entre el paganismo y el nuevo mundo cristiano. Nuestro objetivo será analizar los procedimientos y estrategias empleados por los pintores para manifestar esta ruptura.

\section{PALABRAS CLAVE}

Paganismo. Tiziano. Prudencio. Martirio. San Lorenzo. Renacimiento.
Anuario del Departamento de Historia y Teoría del Arte

vol. 32, 2020, pp. 29-45

ISSN: 1130-5517, eISSN: 2530-3562

https://doi.org/10.15366/anuario2020.32.002

\begin{abstract}
In his Liber Peristephanon, Prudentius promotes the Christianisation of space through the worship of saints and the veneration of relics. In this manner, the poet and Father of the Church joins the effort of the Christians of the fourth century to take ownership of the imperial territory through the development of a network of holy places. A detailed reading of this text allows us to deduce that it was the martyr's passive resistance -especially that of Saint Lawrence- that ended the realm of pagan gods in Rome and in the Empire. The influence of Prudentius' text led Titian -and, later, other artists- to introduce in his representations of the martyrdom of Saint Lawrence a message that highlights the opposition between paganism and the new Christian world. Our goal is to analyse the procedures and strategies used by painters to manifest this break.
\end{abstract}

\section{KEY WORDS}

Paganism. Titian. Prudentius. Martyrdom. Saint Lawrence. Renaissance. 
El objetivo de esta contribución será analizar cómo, a través de las obras figurando el martirio de San Lorenzo, ciertos artistas del Renacimiento hacen referencia a la cristianización del espacio pagano. Nos concentraremos, en particular, en las representaciones realizadas por Tiziano que toman como fuente el Peristephanon de Prudencio y que están en la base de una innovación iconográfica que dotaría a este episodio de nuevos significados. Sin embargo, antes de interesarnos por las representaciones pictóricas, examinaremos la hagiografía relativa a san Lorenzo y recontextualizaremos el texto de Prudencio.

El hecho de que el nombre del santo figure en la Depositio martyrum del año 354 nos indica que la veneración del mártir remonta al menos al siglo IV ${ }^{1}$. Luego, hacia fines de aquel siglo, san Ambrosio de Milán incluyó ciertos episodios de la vida de Lorenzo en su De officiis ministrorum ${ }^{2}$. Por su parte, Prudencio, "el principal poeta cristiano de la antigüedad latina", le dedicó uno de los himnos de su Liber Peristephanon, escrito entre fines del siglo IV y principios del siglo $\mathrm{V}^{4}$. No obstante, el escrito de más autoridad en lo que concierne a la vida del santo es la Passio Polychronii ${ }^{5}$, un texto anónimo de fines del siglo V que narra los suplicios de un grupo de mártires, entre los cuales se encuentra Lorenzo ${ }^{6}$. Esta obra debería mucho no solo al texto de san Ambrosio, sino también a una Passio Santi Xysti, Laurentii et Yppoliti redactada en el siglo IV, probablemente en Roma. Si bien este último texto no se ha conservado hasta nuestros días, los investigadores han podido reconstruir sus principales episodios a partir de los relatos que derivan de él ${ }^{7}$.

Llegado este punto, es necesario evocar rápidamente el desarrollo iconográfico de las representaciones de san Lorenzo. Como ha señalado Simonetta Serra, las imágenes de los primeros siglos del cristianismo que se conservan hasta nuestros días no figuran a Lorenzo en el momento de su martirio, sino como miembro de la Iglesia Triunfante, en compañía de Cristo y de otros $\operatorname{santos}^{8}$. Son ejemplo de ello la colección de vidrios dorados conservada en el Vaticano (mediados del siglo IV, fig. 1) , el mosaico del mausoleo de Galla Placidia (pri-

1 El más antiguo de los calendarios de la Iglesia Romana conmemora a san Lorenzo en los siguientes términos: "El cuarto día antes de los idus de agosto: aniversario de Lorenzo, vía Tiburtina". Esta nota es ratificada en el Martirologio Jeronimiano, donde se menciona, además, el lugar de sepultura del mártir y su cargo de archidiácono.

2 San Ambrosio se refiere a Lorenzo en dos ocasiones en dicho texto: I, 41, 205-207 y II, 28, 140-141. También menciona al santo en su carta XXXVII y en un himno que se le atribuye. Consultar: Cécile LANERY, "Du magistère au ministère: remarques sur le De officiis d'Ambroise de Milan", L’information littéraire, vol. 58/3 (2006), pp. 3-9; Hippolyte DeLEHAYE, "Recherches sur le légendier romain”, Analecta Bollandiana, 51 (1933), pp. $34-93$ (aquí: p. 50). Los escritos de Ambrosio son, junto a los del papa Dámaso I, de los más antiguos que se conservan haciendo referencia a la vida de Lorenzo. Recordemos que Dámaso escribió un epigrama dedicado al santo en la basílica de San Lorenzo fuori le Mura: "Verbera carnifices flammas tormenta catenas vincere Laurenti sola fides potuit. Haec Damasus cumulat supplex altaria donis martyris egregii suspiciens meritum" ("Látigos, garfios, llamas, tormentos, cadenas, solo la fe de Lorenzo pudo vencerlas. Dámaso suplicante colma estos altares de presentes admirando los méritos del glorioso mártir”). El epigrama damasiano sería unos años anterior al De officiis, ya que el texto de san Ambrosio habría sido escrito no antes del 386, mientras que Dámaso murió en 384. Ver: Antonio FerruA, Epigrammata damasiana, Roma, Pontificio Istituto di Archeologia cristiana, 1942, p. 167; Simonetta SERRA, "Le fonti e l'archeologia. Alle origini del culto di San Lorenzo a Roma", en R. Passarella (dir.), Il culto di San Lorenzo tra Roma e Milano: dalle origini al Medioevo, Roma, Bulzoni, 2015, pp. 29-54 (aquí: p. 35).

3 Lorenzo JimÉnez PATÓn, "Prudencio y la tradición adversus Judaeos", en C. del Valle Rodríguez (dir.), La Controversia judeocristiana en España, Madrid, CSIC-Instituto de Filología, 1998, pp. 21-42 (aquí: p. 30).

${ }^{4}$ El poeta habría decidido organizar poemas anteriores y compuesto la Prcefatio hacia 404. Ver: Pierre-Yves Fux , Les sept passions de Prudence, Friburgo, Editions Universitaires Fribourg, 2003, p. 8.

5 Es de remarcar que el núcleo central de este texto son los martirios del papa Sixto II y de san Lorenzo.

${ }^{6}$ Este texto fue en parte elaborado a partir de escritos anteriores, como aquellos de san Ambrosio, san Agustín y san Máximo, y completado con leyendas populares de la tradición oral romana.

7 Consultar: Giovanni Nino VerRANDo, "Passio SS. Xysti Laurentii et Yppoliti. La trasmissione manoscritta delle varie recensioni della cosiddetta Passio vetus", Recherches Augustiniennes, vol. 25 (1991), pp. 181-211, passim; Giovanni Nino VerRANDO, "Intorno alla più antica passio dei santi Abdon e Sennes, Sisto, Lorenzo ed Ippolito", Augustinianum, 30 (1990), pp. 145-187, passim; Gérard NAUROY, "Le martyre de Laurent dans l'hymnodie et la prédication des IVe et Ve siècles et l'authenticité ambrosienne de l'hymne", Revue d'Etudes Augustiniennes et Patristiques, 35 (1989), pp. 44-82, passim; Hippolyte DeLEHAYE, "Recherches sur le légendier romain. Passio Polychronii”, Analecta Bollandiana, 51 (1933), pp. 72-98 (aquí: p. 71).

8 Serra, 2015, p. 29.

9 Ver: Lucy GRIG, "Portraits, Pontiffs and the Christianization of Fourth-Century Rome", Papers of the British School at Rome, vol. 72 (2004), pp. 203-230. 
mera mitad del siglo V, fig. 2) ${ }^{10}$, los frescos de la catacumba de San Senatore en Albano Laziale (fines del siglo V, fig. 3), aquellos de la catacumba napolitana de San Gennaro (fines del siglo V o comienzos del siglo VI, fig. 4), el mosaico del arco triunfal de la basílica romana de San Lorenzo fuori le Mura ${ }^{11}$ (siglo VI, fig. 5) o aquel de San Apolinar el Nuevo en Rávena (siglo VI, fig. 6). Una excepción a esta iconografía triunfal en las obras paleocristianas sería la medalla de Sucessa (fig. 7), datada del siglo IV, que hoy conocemos gracias a una matriz de plomo conservada en los Museos Vaticanos y a un dibujo perteneciente a la Colección Durazzo. Sin embargo, su autenticidad ha sido puesta en duda por numerosos historiadores del arte ${ }^{12}$. Es importante remarcar que, a pesar de que ninguna representación del martirio de san Lorenzo realizada en los primeros siglos de nuestra época haya sido conservada, el Liber Pontificalis nos informa que este episodio habría sido figurado en un relieve en plata albergado antiguamente en San Lorenzo fuori le Mura ${ }^{13}$.

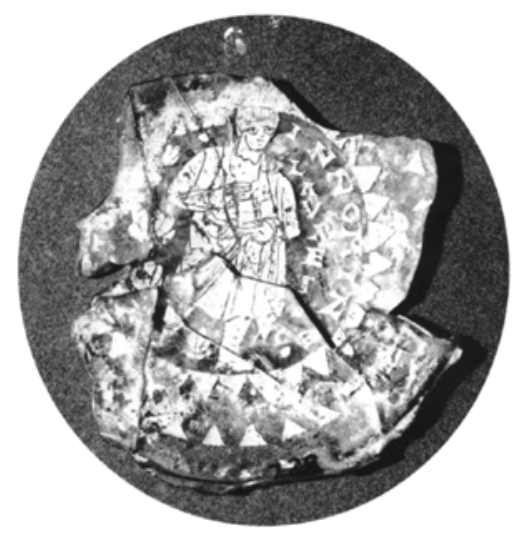

Fig. 1. San Lorenzo, mediados del siglo IV, vidrio dorado. Ciudad del Vaticano, Museos Vaticanos.

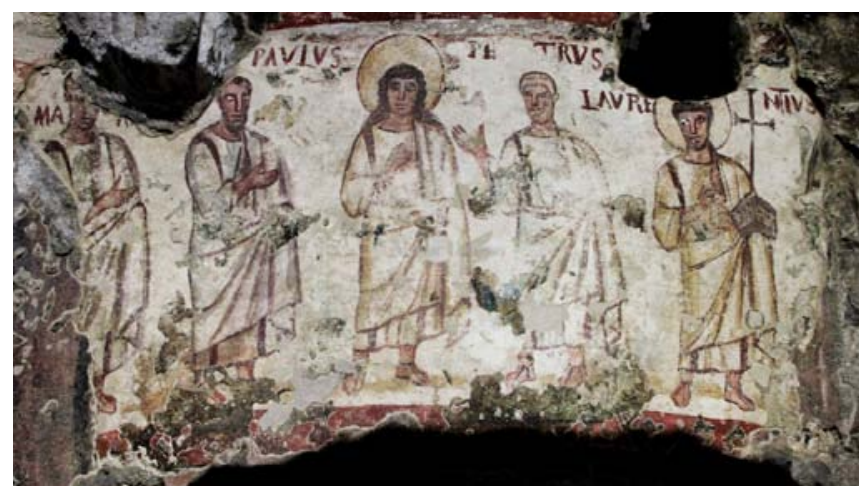

Fig. 3. Cristo entre san Pedro, san Pablo, san Lorenzo y otro santo, siglo V, pintura al fresco. Albano Laziale, Catacumba de San Senatore.

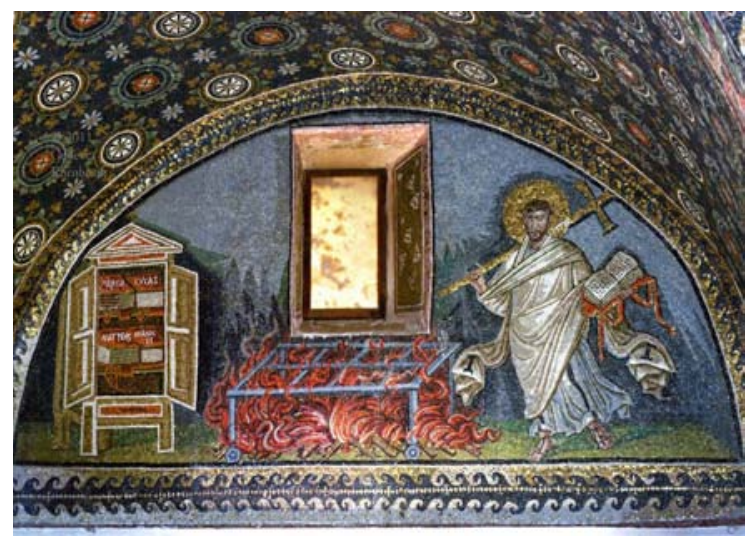

Fig. 2. San Lorenzo, primera mitad del siglo V, mosaico. Rávena, Mausoleo de Galla Placidia.

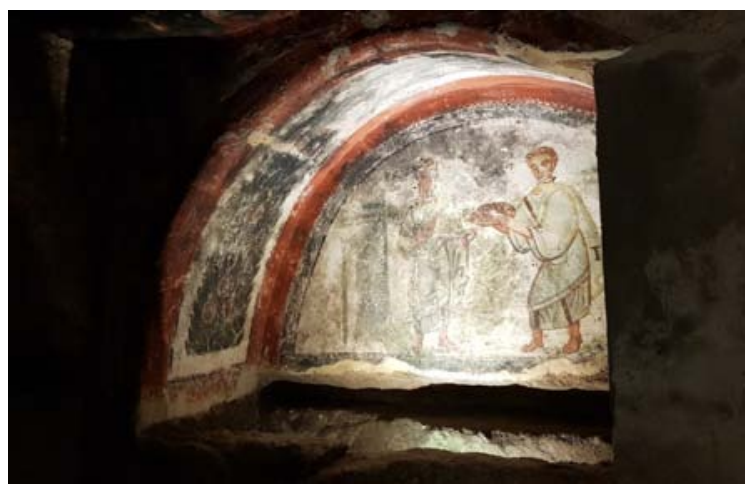

Fig. 4. San Pablo y san Lorenzo, fines del siglo V o comienzos del siglo VI, pintura al fresco. Nápoles, Catacumba de San Gennaro.

10 A pesar de la presencia de la parrilla, el momento representado no es el del martirio.

11 Lugar de entierro del santo.

12 Se trataría, en efecto, de una falsificación del siglo XVIII. Consultar particularmente: Fabrizio BISCONTI, "Dentro e intorno all'iconografia Romana: dal vuoto figurativo all' immaginario devozionale”, en M. Lamberigts, P. Van Deun (eds.), Martyrium in Multidisciplinary Perspective: Memorial Louis Reekmans, Lovaina, Peeters Publishers, 1995, pp. 247-292 (aquí: pp. 252-253).

13 “(posuit) ante corpus beati Laurenti martyris argentoclusas sigillis passionem ipsius cum lucernas binixes argenteas". Ver: Louis Marie Duchesne, Cyrille Vogel (eds.), Liber Pontificalis, vol. I, París, Bibliothèque des Écoles françaises d'Athènes et de Rome, 1955, p. 181. 


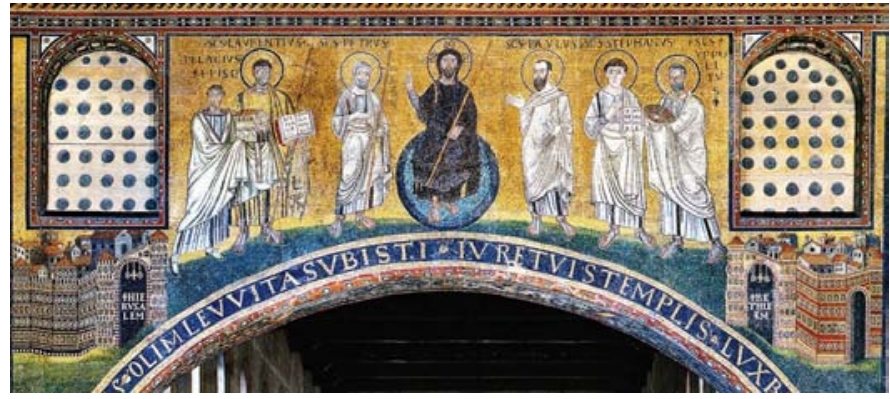

Fig. 5. Jesús entre santos y el papa Pelagio, siglo VI, mosaico. Roma, San Lorenzo fuori le Mura.

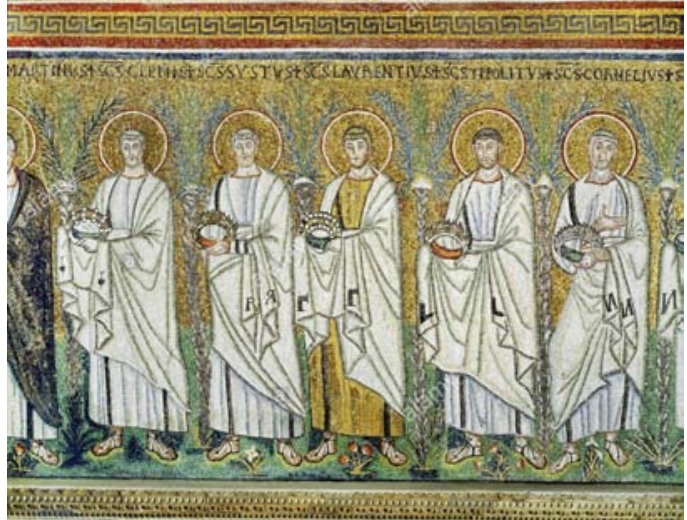

Fig. 6. Procesión de santos mártires, siglo VI, mosaico. Rávena, San Apolinar el Nuevo.
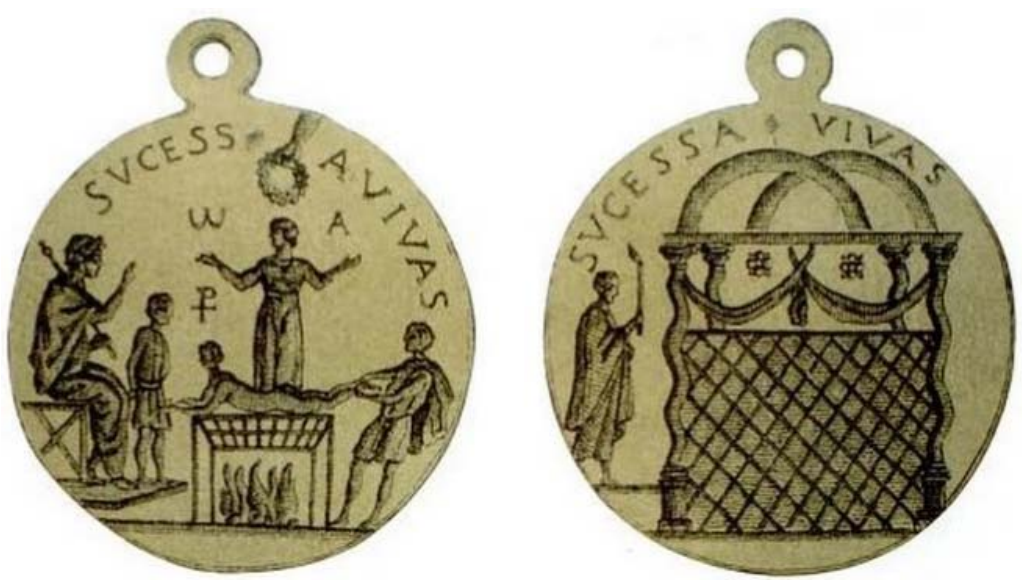

Fig. 7. Medalla de Sucessa, siglo IV o falsificación del siglo XVIII, matriz de plomo. Ciudad del Vaticano, Museos Vaticanos.

Durante el medioevo, el santo conservó una posición privilegiada tanto en la devoción popular como en la literatura. A partir del año mil, los textos en latín fueron traducidos y pasaron a formar parte de los martirologios franceses, italianos, anglo-normandos y españoles ${ }^{14}$. Cabe destacar que gran parte de la literatura hagiográfica de esta época toma como base la ya mencionada Passio Polychronii, de la cual también es tributaria la Leyenda dorada. En esta última, Jacobo de la Vorágine amplía las crónicas precedentes con noticias no solo biográficas, sino también políticas y sociales, y -por otra parte- profundiza en la idea, ya antigua, de que el martirio de san Lorenzo prevalecería sobre aquellos de los demás santos. Con respecto al aspecto iconográfico, cabe destacar que, a partir de comienzos del siglo IX, la representación del suplicio de san Lorenzo se hace más frecuente, tanto en frescos como en relieves y

14 En esta época se contaban cerca de treinta iglesias dedicadas a Lorenzo en la ciudad de Roma, lo que lo convertía en el más ilustre de los mártires post-apostólicos. Ver: Jan ZIOLKOWSKI, The passion of St. Lawrence. Epigrams and marginal poems, Nueva York, E. J. Brill, 1994, p. 52; Hermann GeERTMAn, “Cripta anulare 'ante litteram': forma, contesto e significato del monumento sepolcrale di San Lorenzo a Roma”, en M. Lamberigts, P. Van Deun (ed.), Martyrium in multidisciplinary perspective. Memorial Louis Reekmans, Lovaina, Leuven University Press, 1995, pp. 125-155 (aquí: pp. 125-129). 
manuscritos iluminados ${ }^{15}$ (fig. 8). Las características formales desarrolladas en esta época -es decir, la representación de Lorenzo sobre la parrilla, rodeado de entre dos y cinco verdugos (alguno de los cuales se sirve de un fuelle para atizar el fuego, mientras que otros pican al santo o lo atan) y Decio mirando la escena desde uno de los lados de la composición ${ }^{16}$ - perduran en las representaciones románicas y góticas, así como en aquellas del primer Renacimiento.

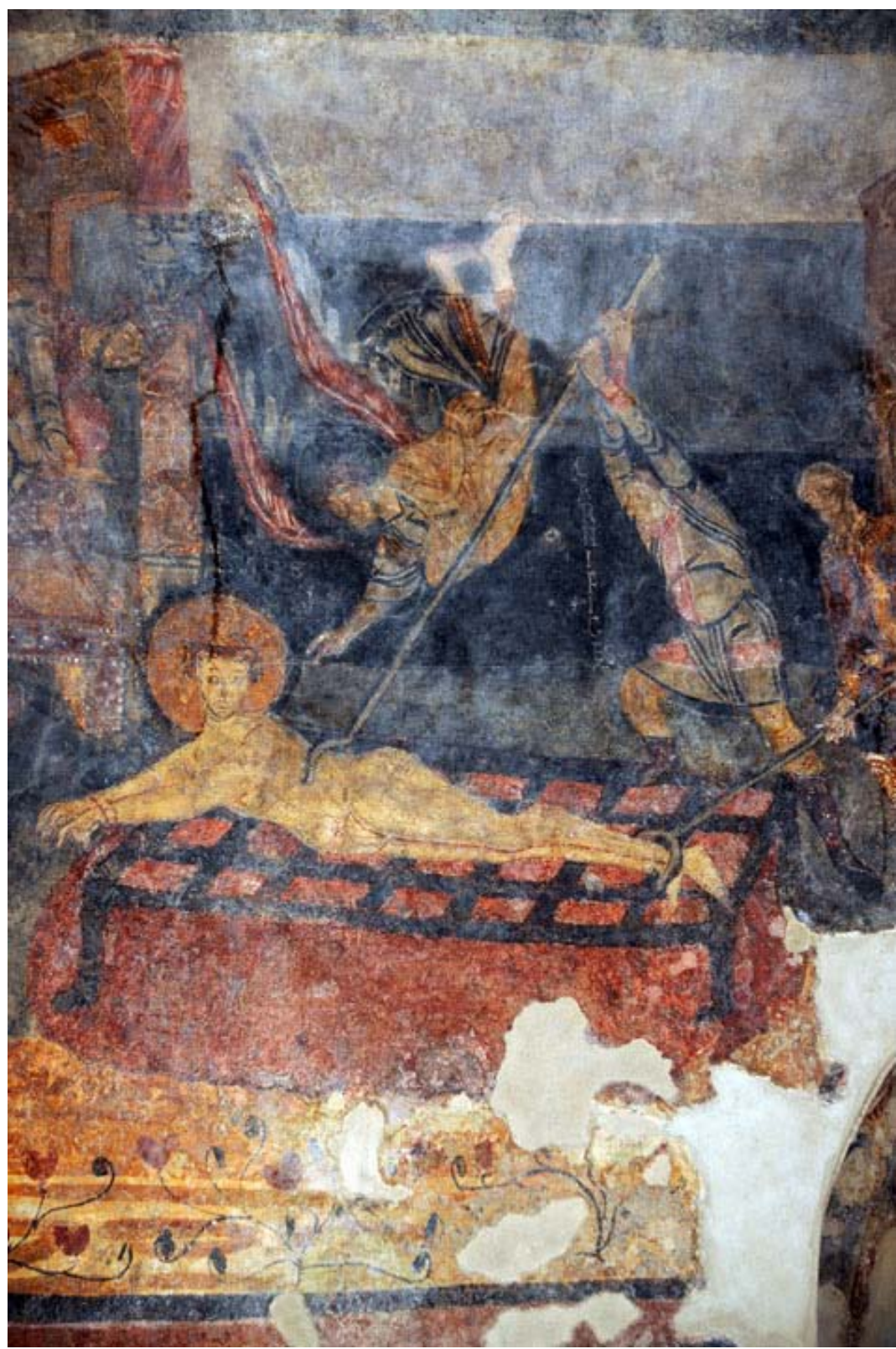

Fig. 8. Martirio de san Lorenzo, 824-842, pintura al fresco. Isernia, Abadía de San Vincenzo al Volturno.

15 SERRA, 2015, p. 53.

16 Ver, por ejemplo, el fresco de la cripta de San Epifanio en la abadía de San Vincenzo al Volturno, realizado entre 824 y 842. 
Si bien en ciertos de los textos que hemos mencionado hay referencias sumarias al paganismo -lo cual es un lugar común en las hagiografías de los mártires que vivieron en los primeros siglos del cristianis$\mathrm{mo}^{17}$-, el Peristephanon de Prudencio se distingue del resto en este aspecto, y no solamente multiplica los ataques a la idolatría, sino que también muestra a san Lorenzo como un nuevo Augusto, líder de la Roma cristianizada. Esto refleja las inquietudes de la época en que Prudencio produjo su obra, caracterizada tanto por la lucha contra las herejías y divisiones dentro de la Iglesia ${ }^{18}$, como por el combate contra el culto pagano ${ }^{19}$. Esta última circunstancia se ve claramente reflejada en los escritos del poeta, quien, en su poema Contra Símaco ${ }^{20}$ retoma la controversia respecto al restablecimiento del altar de la Victoria-símbolo de la religión pagana- en la Curia romana. Recordemos que este altar y su estatua de oro habían sido colocados allí por Augusto en el año 29 a. C., luego de su triunfo en Accio, y que habían sido retirados en 382 por orden de Graciano. Al año siguiente, luego de que este último fuera asesinado, Quinto Aurelio Símaco solicitó al nuevo emperador, Valentiniano II, el restablecimiento del altar. Sin embargo, esta petición quedó en la nada gracias a dos cartas que san Ambrosio dirigió a Valentiniano ${ }^{21}$. Prudencio retoma en su texto los argumentos ambrosianos y elabora, a partir de ellos, una "teología política"22 impregnada de patriotismo romano y de reivindicaciones cristianas.

Este impulso anti-pagano se refleja también en el Peristephanon, donde se promueve la cristianización del espacio a través del culto a los mártires y la devoción a sus reliquias. El poeta sitúa, en efecto, la veneración de cada santo en un marco geográfico preciso y sugiere que el carácter sagrado de las reliquias se transmite al lugar por contacto ${ }^{23}$. De esta manera, forja "leyendas cristianas locales" asociadas a la memoria de un mártir, y las une a sitios precisos del Imperio ${ }^{24}$. En esta estrategia de cristianización del espacio, el rol de la ciudad de Roma es, claro está, central. Prudencio retoma la paronimia entre urbs y orbis, y la transpone a un contexto cristiano ${ }^{25}$. Pero el poeta elabora igualmente un doble de la capital, la Roma caelestis, lo que apunta a acentuar la importante misión de la ciudad, así como su destino. Según Pierre-Yves Fux, "Roma [...] ha tomado el lugar de Jerusalén; el pueblo elegido, del que la conversión completa un oficio universal, no es el de los judíos [...] sino el de la Urbs"26. Cabe destacar, finalmente, que, según el texto de Prudencio, el principal factor que separaba a los habitantes de Roma del cristianismo era la idolatría. De allí, sin duda, la severa crítica del poeta hacia ella: la adoración de falsos dioses era el último escollo a franquear para que Roma y la cultura clásica fueran integradas al cristianismo y cumpliesen, de ese modo, su misión definitiva.

17 Al respecto, es necesario recordar que Alain Boureau ha demostrado que, en textos como la Leyenda Dorada, la repetición de ciertos episodios - como, por ejemplo, aquellos de destrucción de ídolos - tiene por objetivo la unificación del relato. De esta forma, el autor logra que el aspecto didáctico de su obra esté por encima de las historias individuales de cada santo. Consultar: Michael CAmille, The Gothic Idol: Ideology and Image-Making in Medieval Art, Cambridge, Cambridge University Press, 1991, p. 122.

18 Fundamentalmente el arrianismo, el donatismo y la pneumatomaquia. Para profundizar sobre los grandes debates de esta época, consultar: Robert Austin MArkus, The End of Ancient Christianity, Cambridge, Cambridge University Press, 1990 , passim.

19 Recordemos que la ofensiva neo-pagana (361-363) de Juliano el Apóstata se dio durante la vida de Prudencio.

20 La primera redacción del Libro 1 podría situarse hacia 391, y habría tenido correcciones hacia 399, mientras que el Libro 2 habría sido terminado hacia 402-403. Ver: Fux, 2003, pp. 8, 44.

21 Epístolas 17 y 18.

22 François PASCHOUd, Roma ceterna. Études sur le patriotisme romain dans l'Occident latin à l'époque des grandes invasions, Roma, Institut Suisse de Rome, 1967, p. 222.

${ }^{23}$ La mayoría de los textos del Peristephanon comienzan con una evocación del lugar elegido para albergar la tumba del santo mártir. Consultar: Michael RoBerTs, Poetry and the Cult of the Martyrs. The Liber Peristephanon of Prudentius, Ann Arbor, University of Michigan Press, 1993, p. 10.

24 Joëlle Soler, "Religion et récit de voyage. Le Peristephanon de Prudence et le De reditu suo de Rutilius Namatianus", Revue des études augustiniennes et patristiques, 51 (2005a), pp. 297-326 (aquí: pp. 304-311).

25 Soler, 2005a, p. 311. Por otro lado, los paralelos entre el Peristephanon, 2 y la Eneida, 1 y 6 "muestran la tentativa de Prudencio de reestructurar la literatura pagana y de forjar un arte literario cristiano". Consultar: William MCCARTHY, "Prudentius, Peristephanon 2: Vapor and the Martyrdom of Lawrence", Vigiliae Christianae, 36, 3 (1982), pp. 282-286 (aquí: p. 283 ).

26 Fux, 2003, p. 150. 
Prudencio se inscribe, de esta forma, en el esfuerzo de los cristianos del siglo IV para apropiarse del territorio imperial a través de la creación de una red de lugares santos ${ }^{27}$. Como lo ha recalcado Joëlle Soler, "si la teología cristiana rompe con el paganismo afirmando que [...] Dios se encuentra donde sea que el fiel rece [...], si, entonces, durante un largo tiempo, los cristianos habitan un universo espacial en gran medida neutro, progresivamente, en la práctica, tienden a tomar posesión de los lugares del Imperio demasiado marcados a sus ojos por las referencias a la religión pagana" 28 . Recordemos que esta conquista del espacio había sido comenzada por el papa Dámaso (304-384), que hizo grabar epigramas rememorando la vida de los mártires en los lugares santos de Roma, colocando así, sobre estos últimos, "una marca de propiedad, a nombre de la Iglesia" 29 .

Examinemos ahora cómo es que el texto de Prudencio ha contribuido a que el episodio del martirio de san Lorenzo se convirtiese en un caso paradigmático de cristianización del espacio pagano. La Pasión del bienaventurado mártir Lorenzo es uno de los 14 poemas que componen el Peristephanon ${ }^{30}$. Lo que nos interesa particularmente de este texto es su insistencia sobre el hecho de que el suplicio sufrido por el santo habría favorecido la cristianización de Roma. Efectivamente, ya desde el comienzo del poema, el autor interpela a la Ciudad Eterna en estos términos:

Anciana madre de los templos, en adelante ofrecida a Cristo, Roma, victoriosa bajo la conducción de Lorenzo, tú triunfas sobre el culto bárbaro. Has vencido a reyes orgullosos, has sometido a pueblos con tus riendas; es ahora a los ídolos monstruosos que impones el yugo de tu imperio. Solo esta gloria faltaba a las insignias de la Ciudad togada: haber contenido la barbarie del pueblo y domado al inmundo Júpiter, no gracias a las fuerzas tumultuosas de Coso, de Camilo o de César, sino a las del mártir Lorenzo, en un combate donde la sangre no estuvo ausente ${ }^{31}$.

Cabe destacar que, en relación a las hagiografías y martirologios que hemos mencionado anteriormente, Prudencio adiciona, en su texto, una plegaria de Lorenzo por la conversión de Roma y sus habitantes ${ }^{32}$. En ella, el mártir declara que la liberación de la ciudad habría sido comenzada por Pedro y Pablo: "Apártate, Júpiter adúltero [...] abandona esta Roma liberada, ¡huye lejos del pueblo que pertenece ahora a Cristo! Pablo te destierra, la sangre de Pedro te expulsa de aquí" 33 .

Sería entonces la resistencia pasiva de los mártires la que habría terminado con el reino de los dioses paganos que alejaron a los ciudadanos romanos de $\operatorname{Dios}^{34}$. Lorenzo muere al tiempo que concluye su discurso, y luego Prudencio continúa: "A partir de ese día, el culto a los dioses infames perdió su fervor" 35 .

27 Por una parte, el poeta critica los grandes santuarios y los lugares de memoria paganos, promoviendo una nueva geografía, inspirada por el cristianismo. Por otro lado, re-emplea los procedimientos de la descripción geográfica propios a la paideia greco-latina, sustituyendo los referentes paganos por referentes cristianos. Ver: SOLER, 2005a, pp. 298, 307-309; Joëlle SOLER, Ecritures du voyage. Héritages et inventions dans la littérature latine tardive, París, Études Augustiniennes, 2005b, passim; RoBERTs, 1993, passim; Peter Brown, The Cult of the Saints: Its Rise and Function in Latin Christianity, Londres, The University of Chicago Press, 1981, p. 21.

28 SOLER, 2005a, pp. 306, 326.

29 Fux, 2003, pp. 31-32. Consultar también: SOLER, 2005a, p. 307.

30 Según Pierre-Yves Fux, el poema dedicado a Lorenzo habría abierto la narración en la configuración inicial, que fue modificada en el Renacimiento. Ver: Fux, 2003, pp. 64-65, 149.

31 Peristephanon, 2, 1-16. Para un comentario sobre el matiz Virgiliano de este elogio a la Roma cristiana, consultar: Fux, 2003, p. 154 y siguientes. Rubén Florio analiza la renovación del arquetipo heroico en la obra de Prudencio en: Rubén FLORIO, "Peristephanon: asimilación y renovación épicas", Latomus, 61, fasc. 1 (2002), pp. 134-151, passim; Rubén FloRio, "Peristephanon: muerte cristiana, muerte heroica", Rivista di cultura classica e medioevale, 44, 2 (2002), pp. 269-279, passim.

32 Peristephanon, 2, 433-456.

33 Peristephanon, 2, 465-470.

34 Prudencio ofrece una visión soteriológica del martirio: este último sería capaz de redimir y de purificar no solamente las almas de los santos, sino también aquellas de sus conciudadanos. De esta forma, si la muerte de Cristo en la cruz salvó a la humanidad del pecado original, la muerte de los mártires contribuiría a la salvación de las almas de sus coterráneos. Consultar: John PETRUCCIONE, "The Martyr Death as Sacrifice: Prudentius, Peristephanon 4. 9-72”, Vigiliae Christianae, 49, 3 (1995), pp. 245-257 (aquí: pp. 246-249).

35 Peristephanon, 2, 497-498. 
El martirio y la muerte del santo marcarían, por lo tanto, un quiebre en la lucha contra el paganismo. Para acentuar el rol del mártir en la cristianización de la ciudad, y para presentarlo como el garante de su lealtad a Cristo, el poeta aproxima al santo a la figura de pater patriae de la Roma caelestis $^{36}$ y señala que goza de un rango consular perpetuo y que porta, en el Paraíso, la corona cívica y la toga picta. Su función civil es, en consecuencia, particularmente enfatizada ${ }^{37}$.

El propósito de Prudencio es, por lo tanto, doble. Por una parte, reformula la misión de Roma, dándole un papel primordial en la conversión del mundo pagano y de sus habitantes. Por otro lado, establece a Lorenzo como el líder de la Roma cristianizada y como el garante de que la Urbs por antonomasia permanecerá leal a Cristo.

El primer artista que se sirvió del texto de Prudencio como fuente principal para la elaboración de la iconografía de un martirio de san Lorenzo fue Tiziano (figs. 9 y 10$)^{38}$. Es por ello que analizaremos, a continuación, las dos versiones de este episodio realizadas por el artista veneciano, así como el grabado ejecutado por Cornelis Cort y aprobado por Tiziano en 1571 (fig. 11). Es fundamental señalar, llegado este punto, que el poema de Prudencio fue editado al menos en 19 ocasiones a lo largo del siglo XVI ${ }^{39}$. De estas ediciones, nos interesan en particular aquellas de Aldus Manutius ${ }^{40}$ y Alvise Lippomano ${ }^{41}$, publicadas en Venecia respectivamente en 1501 y 1553 . En cuanto a la primera, se trata de la edición italiana más antigua de las obras de Prudencio, y es de suponer que el artista conociera personalmente a Manutius y sus asociados ${ }^{42}$. La segunda, por su parte, fue publicada de manera contemporánea a la realización de la primera versión del Martirio de San Lorenzo. Se trata de un texto que se alinea con los preceptos de la naciente política tridentina, proponiendo un nuevo modelo hagiográfico, en el que la antigüedad de las fuentes garantizaría su fiabilidad ${ }^{43}$.

La primera versión tizianesca del Martirio de San Lorenzo (fig. 9) fue encargada en 1548 por el mercader veneciano Lorenzo Massolo para su capilla en la iglesia Santa Maria dei Crociferi. Luego de su muerte, en enero de 1557, fue su esposa, Elisabetta Querini, quien se ocupó de velar por el completamiento de la obra, que sería entregada en 1559. Algunos años más tarde, en agosto de 1564, Felipe II encargaría a Tiziano una variante de esta pintura para el altar mayor de la basílica del Escorial (fig. 10). Sin embargo, el lienzo, finalizado en 1567, no sería colocado en el lugar previsto, sino en la "iglesia pequeña" o "iglesia vieja" del monasterio, ya que sus dimensiones no coincidían con aquellas del nicho central del retablo concebido por Juan de Herrera ${ }^{44}$. Por otro lado "la lejanía y la mala iluminación hacían que los personajes

36 Peristephanon, 2, 569-572.

37 FuX, 2003, p. 151.

38 Aún no se ha demostrado que Tiziano supiese leer el latín. Sin embargo, si no fuese el caso, el pintor podría haber tenido conocimiento de este texto a través de sus amigos Pietro Aretino, Pietro Bembo o Jacopo Sansovino. Consultar: Augusto GENTILI, Da Tiziano a Tiziano. Mito e allegoria nella cultura veneziana del Cinquecento, Roma, Bulzoni, 1988, pp. 249-274; Augusto Gentili, "La notte di Lorenzo", en L. Puppi, L. Lonzi (eds.), La notte di San Lorenzo. Genesi, contesti, peripezie di un capolavoro di Tiziano, Treviso, Terra Ferma, 2013, pp. 90-99 (aquí: p. 91); Irene FAVARETTO, “Tiziano e l'antico: spunti e divagazioni”, en L. Puppi (ed.), Tiziano. L’ultimo atto, Milán, Skira, 2007, pp. 49-53 (aquí: p. 52). Sobre la influencia de los textos de Aretino en algunas de las pinturas de Tiziano, ver: Augusto GeNTILI, "Tiziano e Aretino tra politica e religione", en Pietro Aretino nel cinquecentenario della nascita. Atti del Convegno (Roma-Viterbo-Arezzo, 28 settembre-1 ottobre 1992; Toronto, 23-24 ottobre 1992), Roma, Salerno Editrice, 1995, pp. 275-297.

39 Fux, 2003, pp. 91-100.

40 Poetae Christiani Veteres.

41 Sanctorum priscorum patrum vitae.

42 Cora E. LuTz, “Aldus Manutius, Teacher”, The Yale University Library Gazette, 49, 4, (1975), pp. 356-363 (aquí: p. 361); Robert W. GASTON, "Vesta and the Martyrdom of St. Lawrence in the Sixteenth Century", Journal of the Warburg and Courtauld Institutes, vol. 37 (1974), pp. 358-362 (aquí: p. 359); Joseph Archer Crowe, Giovanni Battista CAVALCASELLE, Titian, his life and times, vol. 1, Londres, John Murray, 1881, pp. 149-151.

43 Michele Di MonTe, "La morte bella. Il martirio nella pittura di Tiziano, Tintoretto e Veronese", Venezia Cinquecento, IX, 17 (1999), pp. 91-179 (aquí: p. 103).

44 La pintura era 9 centímetros más baja y 21 centímetros más estrecha que el nicho donde hubiese debido ser colocada. 


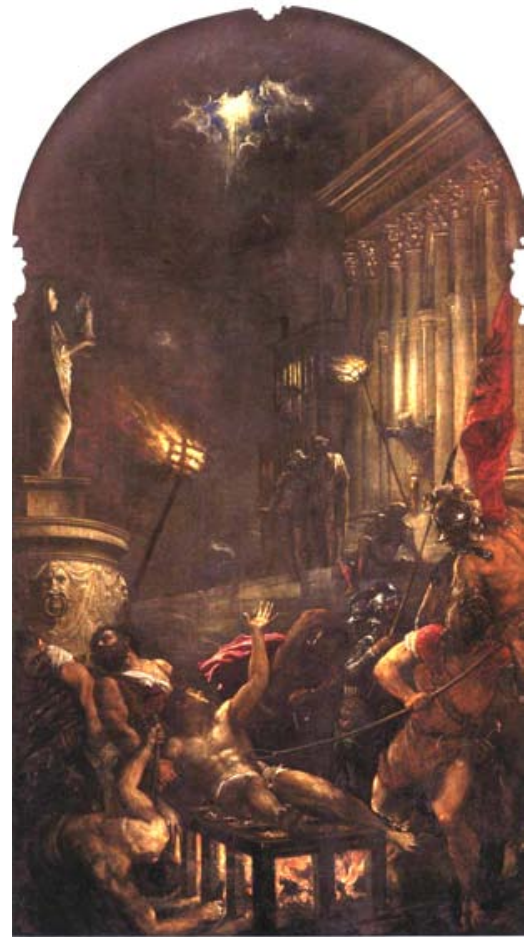

Fig. 9. Tiziano, Martirio de san Lorenzo, 1548-1559, óleo sobre tela. Venecia, Santa Maria Assunta.

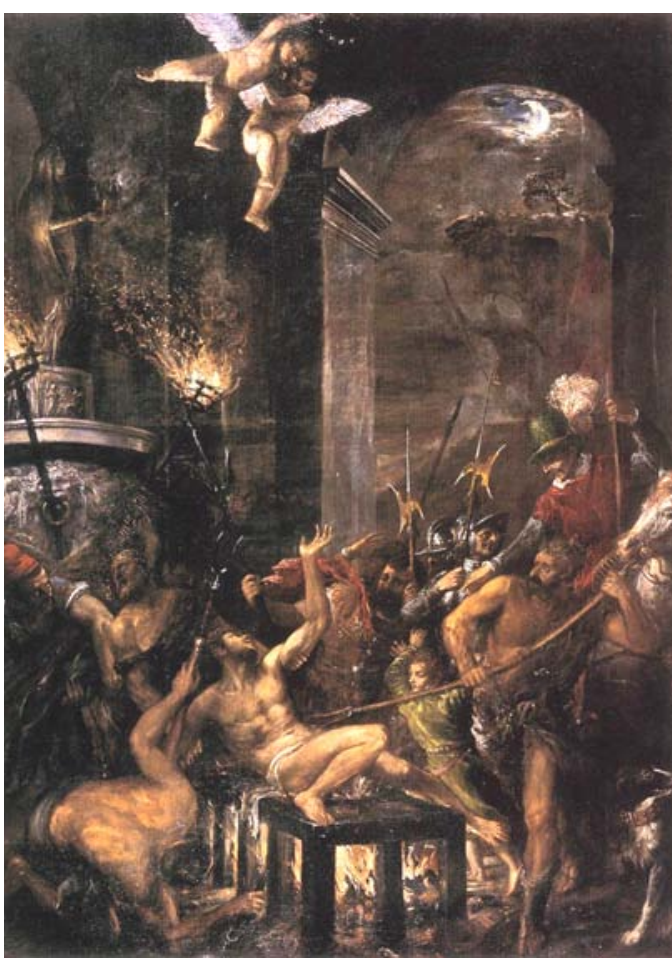

Fig. 10. Tiziano, Martirio de san Lorenzo, 15641567, óleo sobre tela. San Lorenzo de El Escorial, Monasterio de San Lorenzo.

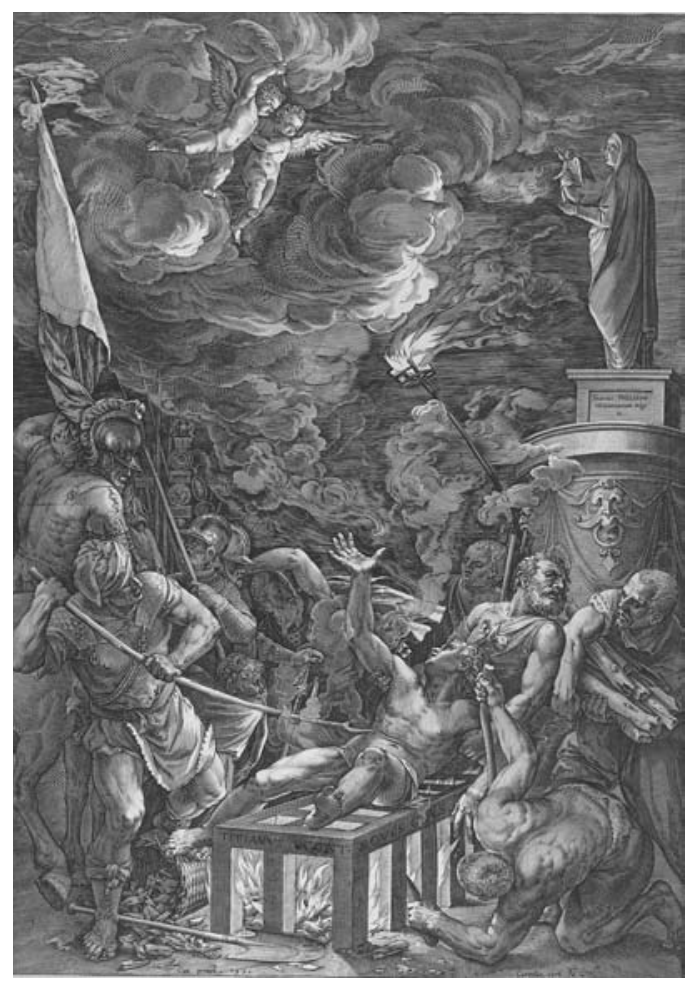

Fig. 11. Cornelis Cort a partir de Tiziano, Martirio de san Lorenzo, 1571, grabado. 
de Tiziano fueran casi invisibles". Recordemos, a este respecto, que los diversos cambios arquitectónicos llevaron a que el retablo fuese una de las partes más oscuras de la iglesia, y a que su iluminación fuese sobre todo frontal ${ }^{45}$. En palabras de José de Sigüenza, la iluminación "reverbera en los ojos el barniz y quita la luz a lo que la pide, y dala donde no es menester" 46 . Las columnas situadas a cada lado de las obras pictóricas debilitan aún más la luminosidad lateral y exacerban este efecto.

Los estudios realizados a la obra escurialense han demostrado que la composición inicial era muy similar al prototipo, es decir, a la pintura de los Crociferi $^{47}$. Sin embargo, en un estadio más avanzado de la realización, Tiziano introdujo ciertos cambios con el objetivo de ajustar la obra a las "exigencias de verosimilitud y proximidad con el espectador propias de la Contrarreforma y que serían más del gusto de Felipe II"48. Entre estas modificaciones, nos interesan especialmente la introducción, bajo la estatua de Vesta, de un plinto rectangular en el que se aprecia un relieve representando una persona sentada en lo que parecería ser un trono y otra de pie, sujetando un báculo. Este relieve ha sido interpretado como una referencia al edicto de persecución proclamado por Valeriano, que conllevaría el arresto y el martirio de numerosos cristianos, entre los cuales san Lorenzo ${ }^{49}$. La segunda modificación que querríamos resaltar es la simplificación del fondo arquitectónico. Las grandes escaleras y la columnata monumental que remiten a un templo pagano ${ }^{50}$ han sido suprimidas y reemplazadas, en la versión escurialense, por dos arcos sostenidos por enormes pilares. En la estampa de Cornelis Cort (fig. 11), que es un cruce de las dos versiones anteriores, este fondo arquitectónico es suprimido completamente y sustituido por un agitado torbellino de volutas de humo que se confunde con las nubes en la parte superior de la composición ${ }^{51}$. Más allá de las diferencias, las tres obras contienen un elemento en común que ha despertado el interés de los historiadores del arte. Se trata de una escultura femenina sobre un pedestal, vestida como una matrona romana y sujetando una estatuilla sobre la palma de la mano. Panofsky ha identificado acertadamente esta figura como la diosa Vesta ${ }^{52}$, a la cual Prudencio

45 Annie Cloulas, "Les peintures du grand retable au monastère de l'Escurial”, Mélanges de la Casa de Velázquez, 4 (1968), pp. 173-202 (aquí: p. 179).

46 José de SigüenZa, Historia de la Orden de San Jerónimo, parte 3, libro 4, 1605.

47 Miguel Falomir, Tiziano, Madrid, Museo Nacional del Prado, 2003, pp. 407-408.

48 Fernando Checa Cremades, Tiziano y las cortes del Renacimiento, Madrid, Marcial Pons, 2013, p. 458.

49 Carmen García-Frías ChecA, Esperanza Rodríguez-Arana MuÑoz, Tiziano y el Martirio de San Lorenzo de El Escorial: consideraciones histórico-artísticas y técnicas tras su restauración, Madrid, Patrimonio Nacional, 2003, p. 29

50 Checa CRemades, 2013, p. 458.

51 En su carta del 13 de marzo de 1567, Domenico Lampsonio dice a Tiziano, luego de haber visto las estampas de Cornelis Cort: "Ho visto poi certe pezze di un martirio di S. Lorenzo d'Inventione di Vostra Signoria che diceva eccellentemente". Como lo ha señalado Lionello Puppi, es de suponer que se tratase de las primeras pruebas para la estampa del Martirio de San Lorenzo. Cort habría, por lo tanto, visto las telas de Tiziano en su primera visita a Venecia, en 1565-1566, es decir, al menos cinco años antes de la fecha de publicación de la estampa. Recordemos, por otro lado, que Tiziano envió este grabado a Felipe II el 1 de agosto de 1571. El artista escribe en su carta: "[...] mandandole due stampe del disegno della pittura del beato Lorenzo, humilissimamente mi raccomando in sua buona gratia". El día siguiente, 2 de agosto de 1571, el embajador Diego Guzmán de Silva escribía al soberano: "[Tiziano] me ha dado una estampa de las que ha hecho en nombre de Vuestra Magestad de San Lorenzo, y la embio con una carta suya". Cabe señalar que, como lo indica la inscripción del pedestal de la estatua de Vesta, la estampa está dedicada al monarca español: "Invictiss. PHILIPPO Hispaniorum Regi D.”. Ver: Lionello PupPI (ed.), Tiziano. L'ultimo atto, Milan, Skira, 2007, p. 415; Matteo MANCINI, Tiziano e le corti d'Asburgo nei documenti degli archivi spagnoli, Venecia, Istituto veneto di scienze, lettere ed arti, 1998, pp. 366-367.

52 Erwin PANOFsKy, Titien. Questions d'iconographie, París, Hazan, 2009, pp. 83-88. Previamente, la estatua había sido aproximada a la Dea Roma. Ver: Ruth Wedgwood KenNEDY, Novelty and Tradition in Titian's Art, Northampton, Smith College, 1963, pp. 14-17. Como lo ha señalado Robert W. Gaston, la representación de Vesta con el Palladium o una Victoria en la mano derivaría de ciertas monedas y medallones romanos. La colección de Hércules de Este, duque de Ferrara, contaba con numerosas obras de este tipo que Tiziano podría haber conocido. Por otro lado, en las décadas de 1540 y 1550, Enea Vico publicó en Venecia numerosos grabados de estas obras antiguas. Es interesante señalar que, en 1548, es decir, el año en que Tiziano recibió el encargo de pintar el Martirio de San Lorenzo, Vico publicó Le imagini con tutti i riversi trovati et le vite degli imperatori tratte dalle medaglie et dalle historie de gli antichi. En ella, se incluyó una representación de Vesta sentada, sosteniendo una Victoria. Ver: GASTON, 1974, pp. 359360. Finalmente, debemos señalar que la primera versión de la pintura del artista veneciano - aquella destinada a la iglesia de los Crociferi y actualmente conservada en Santa Maria Assunta, también conocida como la iglesia de los Jesuitas - ha sido descrita como la obra tizianesca "más densamente poblada de referencias 'arqueológicas". Consultar a este respecto: FAVARETTO, 2007, p. 51.

Anuario del Departamento de Historia y Teoría del Arte, vol. 32, 2020, pp. 29-45. ISSN: 1130-5517, eISSN: 2530-3562 
hace alusión en su Peristephanon: "La muerte de este santo mártir fue en realidad la muerte de los templos; en aquel momento, Vesta notó que los fieles desertaban los Lares de Pallas"53.

En cuanto a la estatuilla presentada por Vesta, Panofsky la identifica como una Victoria. Por otra parte, el historiador sugiere que el grabado de Cornelis Cort debería ser interpretado de manera ligeramente diferente a las composiciones realizadas por el maestro veneciano, debido a que la Victoria "saluda ahora a los ángeles con su brazo derecho", mientras que estos "parecen girarse más hacia la estatua que hacia el mártir" 54 . La diosa sería, entonces, una figura "cripto-cristiana" 55 que ofrecería voluntariamente la Victoria a los ángeles, por lo que estaríamos aquí ante una visión sincrética, donde el paso de una religión a la otra sería percibido como un evento natural, y no como un derrocamiento violento o una sustitución traumática. Sin embargo, esta interpretación debe ser puesta en tela de juicio, ya que existen dos elementos que la debilitan y podrían invalidarla. En primer lugar, el texto de Prudencio es firme en cuanto a su rechazo a la religión pagana y no da cabida a una posible conciliación o a una transición pacífica entre las dos religiones. En segundo lugar, es de destacar que, si admitimos que en la parte superior de la composición Vesta habría ya aceptado al cristianismo como la fe verdadera y estaría ofreciendo la Victoria a los ángeles, sería entonces inexplicable que en la parte baja de la imagen los hombres continúen combatiendo encarnizadamente.

Se ha conjeturado también que la presencia de Vesta en la primera versión del Martirio de san Lorenzo sería una alusión a Elisabetta Querini, esposa del comitente de la obra, Lorenzo Massolo ${ }^{56}$. La figura sobre la palma de su mano no representaría una Victoria, sino el "jeroglífico de la virtud", con el cual se ve a Elisabetta en un naipe perteneciente a un mazo editado en 1681 (fig. 12). Sin embargo, si bien Rodolfo Gallo y Sandro Sponza han demostrado convenientemente que Elisabetta jugó un rol significativo en la comisión de la tela, sus fundamentos en lo que concierne a la posible figuración de la patricia veneciana bajo los rasgos de la diosa son ambiguos e insuficientes. Como lo ha remarcado Augusto Gentili, si la estatua de Vesta pretendía ser alusión a la patricia veneciana, esta era decididamente ambigua ${ }^{57}$. En efecto, la relación de Elisabetta con el monseñor Giavanni della Casa no podría ser definida de "casta", y habría estado al origen del nacimiento de un niño. Por otra parte, la esposa de Lorenzo Massolo frecuentaba a Pietro Bembo, quien le escribió sonetos y cartas que denotan una intimidad que va más allá de la amistad ${ }^{58}$. Es difícil, en consecuencia, pensar que Elisabetta fuera identificada -o se identificase a ella misma- con las virtudes de castidad y de pureza características de Vesta. Por otro lado, la hipótesis de Gallo y Sponza no explica la presencia de la diosa en la segunda obra de Tiziano, ni en aquella de Cornelis Cort, que fueron realizadas para comitentes distintos y bajo circunstancias que no son comparables a las de la tela conservada actualmente en la iglesia Santa Maria Assunta. Despejadas las dudas respecto a la identificación de la estatua, la inspiración de Tiziano en el texto de Prudencio nos parece clara, y esto no solo a causa de la representación de Vesta, sino también -como lo ha señalado Michele Di Monte- debido a la dialéctica elaborada a través de la utilización de la luz ${ }^{59}$-a la que ambos artistas otorgan un rol fundamental en sus

\footnotetext{
53 Peristephanon, 2, 509-512.

54 PANOFSKY, 2009, p. 88.

55 PANOFSKY, 2009, p. 89.

56 Sandro SponzA, "Martirio di San Lorenzo", en F. Valcanover (dir.), Tiziano, Venecia, Marsilio, 1990, pp. 308-312; Rodolfo Gallo, “Per il 'San Lorenzo Martire’ di Tiziano. I committenti, la datazione”, Rivista di Venezia, 14 (1935), pp. 155-174.

57 Augusto Gentili, Tiziano, Milán, 24 ore Cultura, 2012, p. 304; Gentili, 2013, p. 95.

58 Claudia Terribile, "Il doge Francesco Donà e la Pala di San Giovanni Elemosinario di Tiziano", Venezia Cinquecento, VII, 14 (1997), pp. 47-139 (aquí: pp. 123-126).

59 Di Monte, 1999, pp. 98-103. El rol de la luz es central en ambas obras tizianescas, pero adquiere un papel aún más destacado en la segunda versión de la pintura. En efecto, la luz y los efectos de luminosidad "tienen la función de aumentar la intensidad de la historia de manera dramática. Las vivas llamas de las antorchas completan e intensifican la crueldad del momento y hacen eco de la parrilla encendida". Ver: Hilliard GOLDFARB, "Venezia, la Controriforma e gli ultimi dipinti religiosi di Tiziano", en L. Puppi (ed.), Tiziano. L’ultimo atto, Milán, Skira, 2007, pp. 108-109.
} 
respectivas obras- y al carácter "curiosamente anónimo" 60 de la arquitectura -a la que, contrariamente a otras fuentes, Prudencio no hace referencia alguna. Cabe destacar, no obstante, que la utilización de Prudencio como fuente principal no excluye el empleo de otros textos, como, por ejemplo, aquellos de san Ambrosio o san Agustín, como fuentes complementarias ${ }^{61}$.

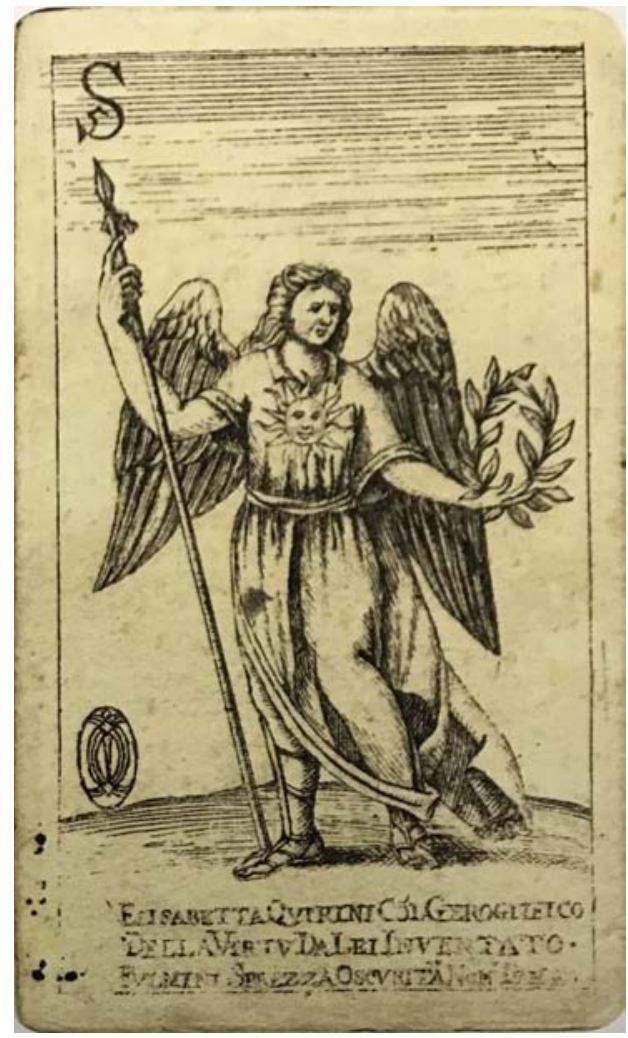

Fig. 12. Naipe representando a Elisabetta Querini con el "jeroglífico de la virtud”, 1681.

La presencia de Vesta en las tres composiciones que nos interesan hace de la diosa un elemento clave para la lectura y la interpretación de estas obras. Cabe entonces preguntarse por qué Tiziano ha representado a Vesta en lugar de Júpiter, que, como hemos visto, también es mencionado por Prudencio. A nuestro entender, la estatua de Vesta debe ser vista aquí no solo como una referencia a los cultos paganos, sino también como un símbolo de la hegemonía imperial y de la cultura clásica. Recordemos que las vestales cuidaban del fuego sagrado - garante del bienestar y de la perennidad del Imperio- en el templo de la diosa. Por otra parte, la Vestal Máxima era la única persona a la que se le permitía ver el Palladium ${ }^{62}$, que, al ser parte de los pignora impe-

60 Gaston, 1974, p. 360. Según Lionello Puppi, la columnata de la parte derecha de la primera composición tizianesca haría referencia al templo de Adriano, mientras que Erwin Panofsky resaltó su cercanía a los templos de Marte Ultor y de Antonino y Faustina, señalando, sin embargo, la "veta fantástica" de la arquitectura. Ver: Lionello PupPI, "Peripezie della Committenza: il contesto, i protagonisti, le occasioni”, en L. Puppi, L. Lonzi (eds.), La notte di San Lorenzo. Genesi, contesti, peripezie di un capolavoro di Tiziano, Treviso, Terra Ferma, 2013, pp. 64-89 (aquí: p. 88); PANOFSKy, 2009, p. 82.

61 Por otra parte, la ambientación nocturna respondería a la Leyenda Dorada de Jacobo de la Vorágine. Ver: Antonio VAnNugLi, "Orazio Borgianni, Juan de Lezcano and a Martyrdom of St Lawrence at Roncesvalles", The Burlington Magazine, 140, 1138 (1998), pp. 5-15 (aquí: p. 14); Di MonTe, 1999, p. 98.

62 Recordemos que se trataba de una imagen de culto de madera (xoanon) representando a Atenea. Del Palladium habría dependido el destino de Troya, primero, y luego el de Roma. 
rii, constituía uno de los objetos que garantizaban la continuidad y la grandeza de Roma ${ }^{63}$. Vesta jugaba, por lo tanto, un rol importante en la perpetuación del Imperio. Esto es fundamental, ya que Prudencio ve en este el ámbito ineludible para el desarrollo del cristianismo: según el poeta, si Roma dio al mundo una misma lengua y una misma sensibilidad, sería también capaz de darle una única religión ${ }^{64}$. El rol de la ciudad en la praeparatio evangelica sería entonces primordial, ya que la Urbs es vista como el marco propicio para la expansión universal del cristianismo. Este último, según la concepción de Prudencio, no estaría aquí para derrocar al Imperio y su cultura clásica, sino para favorecer su continuidad. El poeta promueve, de esta forma, la adaptación de las viejas estructuras y costumbres romanas a los valores y los preceptos cristianos.

La influencia de las composiciones tizianescas ha llevado a los artistas posteriores a dotar sus representaciones del martirio de san Lorenzo de un mensaje que subraya la oposición entre el paganismo y el nuevo mundo cristiano. Para ello, las estrategias adoptadas por los pintores fueron numerosas. Ciertos artistas han evidenciado la superioridad del cristianismo a través de la contraposición entre el lugar central atribuido al santo mártir y aquel periférico dado a los ídolos (figs. 13 y 14). Otro procedimiento para señalar la supremacía cristiana es el de la representación de estatuas de dioses o de emperadores deificados, truncadas plásticamente por los márgenes de la composición (fig. 15).

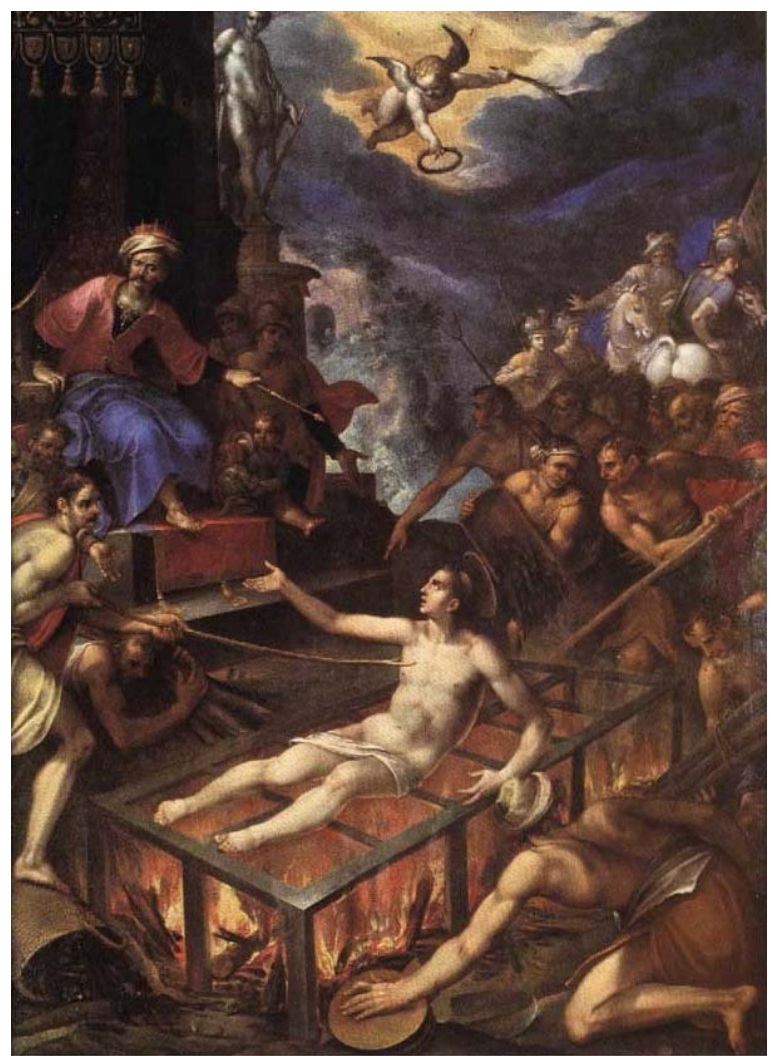

Fig. 13. Siciolante da Sermoneta, Martirio de san Lorenzo, siglo XVI, óleo sobre tela. Veroli, Abbazia di Casamari.

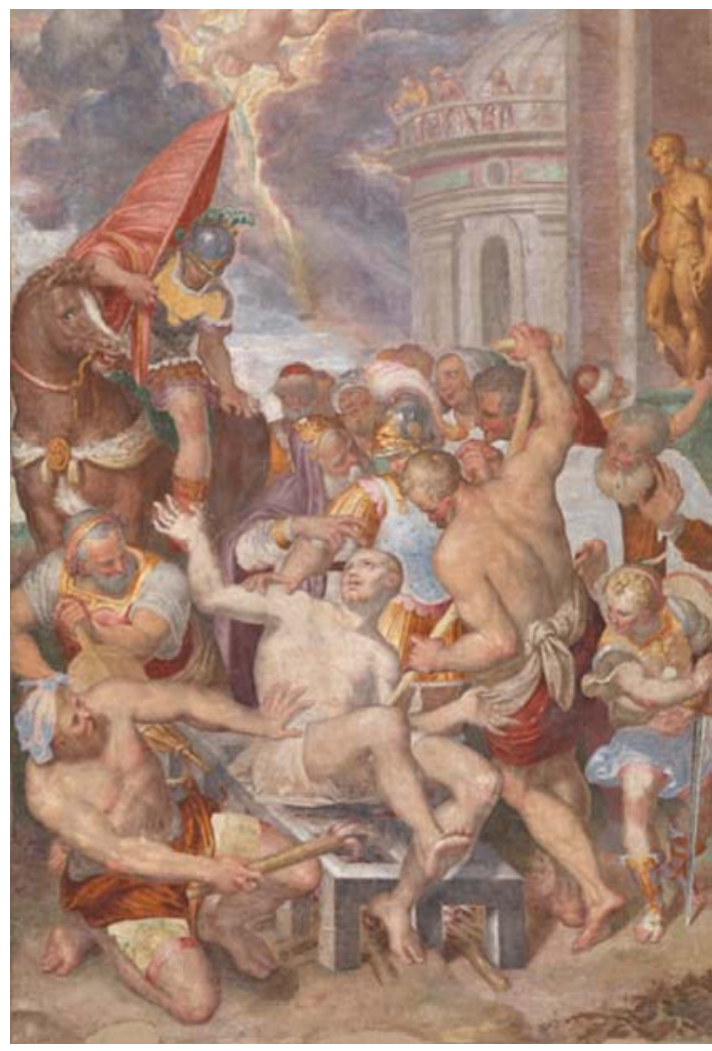

Fig. 14. Aurelio Luini, Martirio de san Lorenzo, hacia 1580, pintura al fresco. Milán, Castello Sforzesco.

${ }^{63}$ Representando a Vesta, Tiziano evoca igualmente la clausura del templo de la diosa y la extinción del fuego sagrado, ordenados por Teodosio en 394. Se trata de eventos contemporáneos a Prudencio, y que propinan un revés importante a la religión pagana.

64 Peristephanon, 2, 425-428, 437-438: "Es así que todos los mortales se situaron bajo la realeza de Remo: tradiciones discordantes hablan ahora la misma lengua y tienen la misma sensibilidad. [...] El orbe se federa en un solo símbolo de fe, el mundo se apacigua". 
La pintura realizada por Orazio Borgianni hacia 1610 y conservada en Roncesvalles (fig. 16) es igualmente representativa del antagonismo entre cristianismo y paganismo. Borgianni figuró, en el centro de la composición, una estatua de Júpiter sobre un enorme capitel corintio que juega el rol de un trono. Esta estatua ha sido aproximada a una aparición ${ }^{65}$. Pensamos, por el contrario, que ella no tiene nada de una visión: está muy presente físicamente, su base es bien visible y hay incluso personajes que la escalan. El pintor ha resaltado la escultura de diversos modos. Por una parte, su posición, en la cima de la composición piramidal, nos lleva a observarla. Por otro lado, el personaje situado a la izquierda del prefecto orienta la atención de este último hacia la estatua. Finalmente, el hecho de que haya personajes que la trepan, crea un movimiento centrípeto que subraya su rol neurálgico en la composición. Sin embargo, el ángel que desciende para dar la palma y la corona del martirio a Lorenzo rompe con esta dinámica, al ser representado no solamente fuera del triángulo en el cual se inscriben todas las demás figuras, sino también al encontrarse sobre un fondo de luz divina. Nos parece interesante señalar el hecho que, si Júpiter tiene el rayo en la mano, es decir, un arma para castigar a sus enemigos, el ángel tiene, por el contrario, la corona y la palma del martirio, con las cuales Dios recompensará a Lorenzo y le ofrecerá la gloria eterna. Hay, por lo tanto, una neta oposición entre el dios pagano, que exige ofrendas, y Dios, que perdona y premia. Esto nos conduce a una última observación. Si el paganismo tiende a elevar a sus dioses, a ponerlos sobre un pedestal, el cristianismo se coloca, por el contrario, al nivel de los que sufren y los recompensa. Remarquemos que el ángel desciende hacia el supliciado para otorgarle los atributos martiriales.

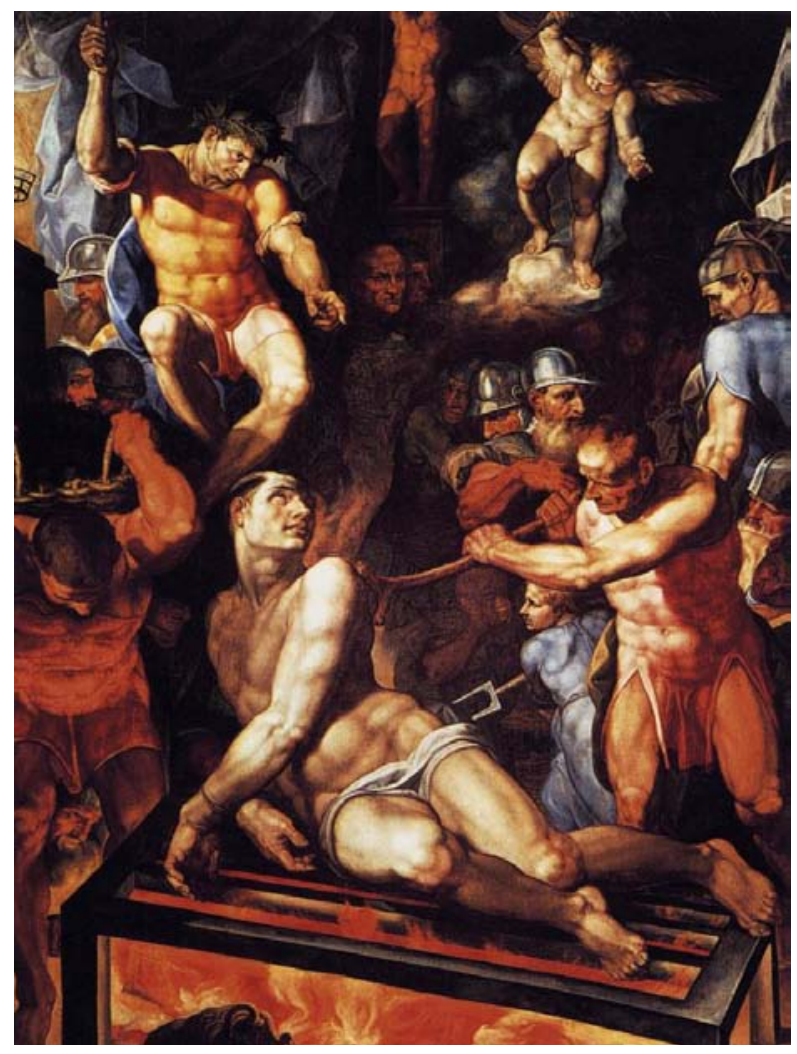

Fig. 15. Pellegrino Tibaldi, Martirio de san Lorenzo, 1592, óleo sobre tela. san Lorenzo de El Escorial, Basílica de San Lorenzo.

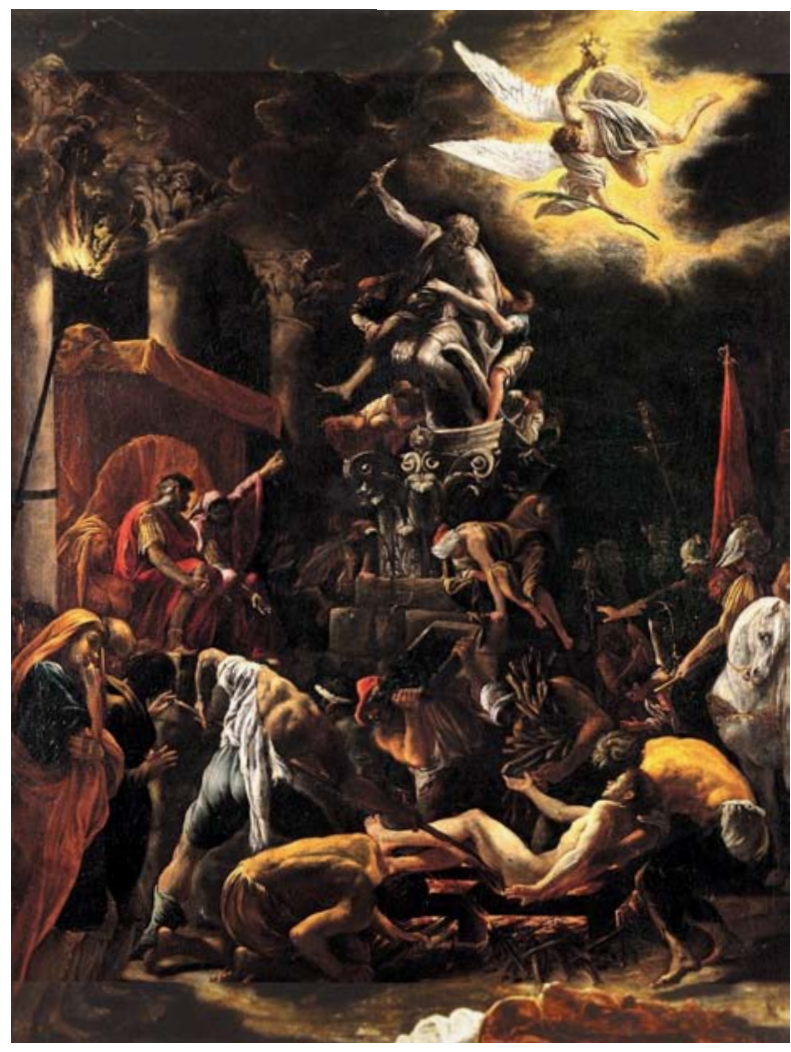

Fig. 16. Orazio Borgianni, Martirio de san Lorenzo, 1610, óleo sobre tela. Roncesvalles, Museo de la Real Colegiata.

65 VANNUGLI, 1998, p. 13. 
La confrontación entre los dos cultos ha sido también enfatizada a través de la oposición entre el eje horizontal y el eje vertical. En la tela de Mattia Preti conservada en Malta (fig. 17), los elementos que hacen referencia al paganismo, es decir, el prefecto, la columna dominada por un ídolo y la figura de Hércules, están distribuidos sobre el eje horizontal. El personaje situado detrás de Lorenzo señala la escultura en bronce, acentuando esta trayectoria. Los elementos cristianos están, por el contrario, ubicados en el centro de la obra, sobre un eje vertical. Por otra parte, la observación que hemos hecho con respecto a la pintura de Borgianni en cuanto a la oposición entre la tendencia a elevar a los dioses paganos y el cristianismo que desciende hacia los que sufren, puede ser aplicada a la obra de Preti.

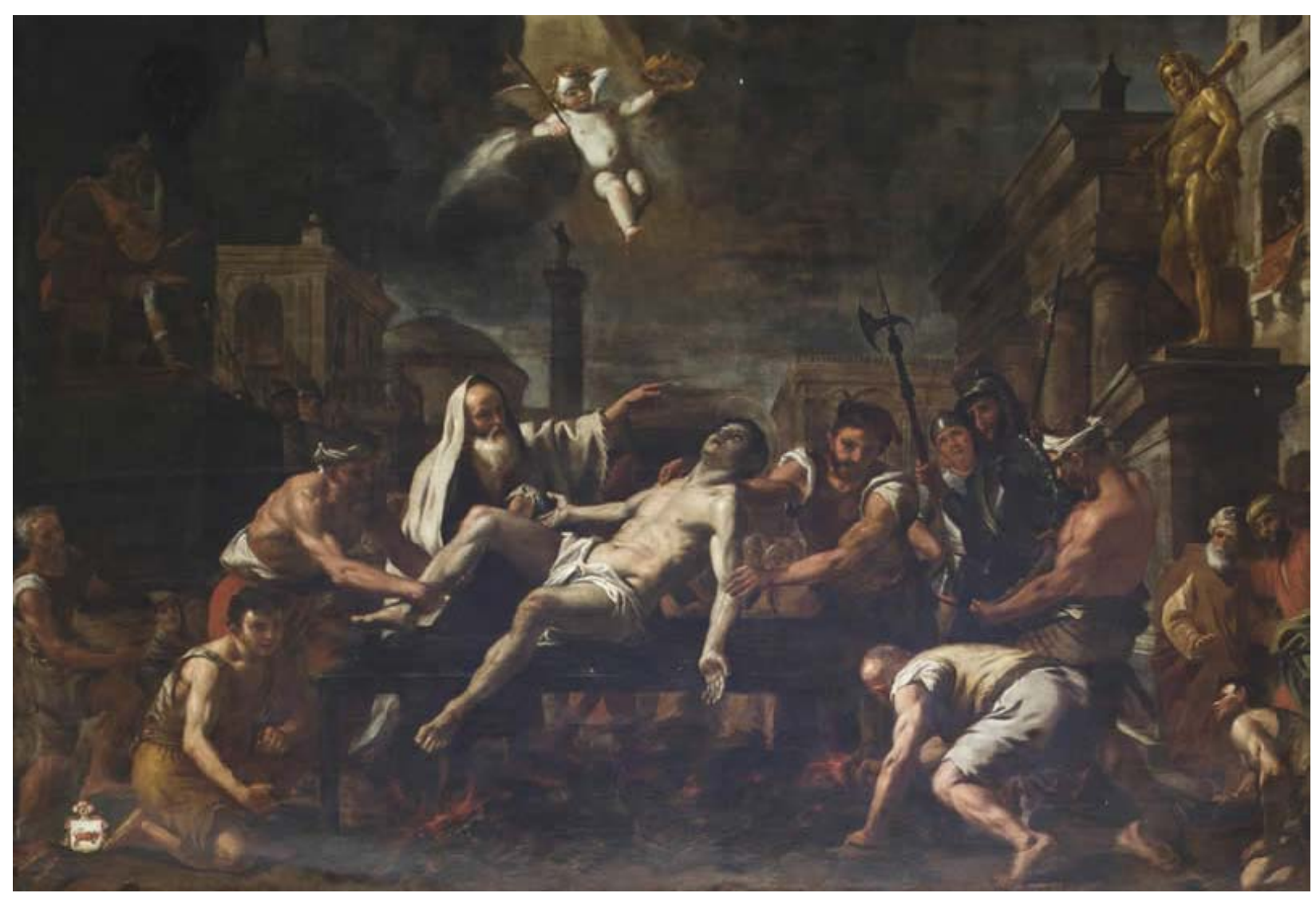

Fig. 17. Mattia Preti, Martirio de san Lorenzo, 1689, óleo sobre tela. Birgu, iglesia San Lorenzo.

¿Por qué, entonces, ha elegido Tiziano y, luego, una gran cantidad de artistas dar una importancia sin precedentes a los elementos paganos en sus representaciones del martirio de san Lorenzo? Para responder a esta pregunta, debemos tener en cuenta que estas pinturas fueron realizadas luego de que las tentativas de conciliación entre los teólogos católicos y protestantes hubieran fracasado ${ }^{66}$. Ellas son, por consiguiente, contemporáneas o posteriores tanto a los debates tridentinos respecto a la política de las imágenes santas como a las reflexiones en cuanto al rol de estas imágenes ${ }^{67}$. Pensamos, en consecuencia, que estas obras

66 Como, por ejemplo, los coloquios de Ratisbona de 1541 y 1446.

67 Domizio Cattoi, Domenica Primerano (dirs.), Arte e persuasione. La strategia delle immagini dopo il Concilio di Trento, Trento, Temi, 2014; Marc Fumarol, De Rome à Paris : peinture et pouvoirs aux XVIIe et XVIIIe siècles, Dijon, Faton, 2007, pp. 16-35; Joseph KoERner, The Reformation of the Image, Chicago, University of Chicago Press, 2003; Alain TAPIÉ (dir.), Baroque, vision jésuite : Du Tintoret à Rubens, París, Somogy, 2003. 
no solo deben ser observadas a través del prisma de la referencia a la antigüedad y del interés por la cultura greco-romana, sino también como una reacción a las críticas por parte de los protestantes. Recordemos que estos últimos cuestionaban la autoridad del papa y de las instituciones eclesiásticas, acusaban a los cristianos de idolatría y percibían las imágenes santas como vectores de superstición, lo cual ocasionaba ataques con respecto al rol de los santos como mediadores.

A pesar de la escasa participación de Venecia en el Concilio de Trento, los habitantes de la Serenísima eran informados de las diversas sesiones de este último por el nuncio apostólico, los mensajeros imperiales y la prensa. Hilliard Goldfarb ha demostrado que la pasividad de Venecia no se debía a cuestiones de índole teológica, sino "al convencimiento de que [el Concilio] serviría esencialmente como pretexto para continuar las guerras imperiales contra los estados alemanes, que iban contra los intereses económicos de la Serenísima"68. Llegado este punto, es importante remarcar que Venecia participaría con un contingente numeroso únicamente en el tercer ciclo de sesiones del Sínodo, que abarcó la discusión sobre las imágenes religiosas. Por otra parte, pocos meses después del fin del Concilio, el Senado emitió una resolución instando la publicación de los decretos tridentinos e invitando a los ciudadanos a respetarlos ${ }^{69}$.

Los artistas que hemos evocado vivieron, al igual que Prudencio, en momentos clave de la historia de la Iglesia, donde esta última debió hacer frente a amenazas tanto internas como externas que coaccionaban para quebrantar sus dogmas. Con el objetivo de proveer una lectura ajustada a los cuestionamientos y dudas inherentes a su propio tiempo, no solo tomaron el texto de Prudencio, sino que también lo actualizaron. La presencia de ídolos paganos en las imágenes que hemos analizado puede ser, entonces, interpretada como una defensa ante las acusaciones reformistas. En primer lugar, a través de este tipo de representaciones, se afirmaba que el cristianismo no solo no caía en prácticas idólatras, sino también que había vencido esta praxis. La Iglesia era presentada, de esta manera, como la promotora, la ejecutora y la garante de la supresión de la superstición, de la cual el paganismo era el practicante por antonomasia. Por otra parte, alegando que la victoria sobre la idolatría se dio, en parte, gracias a la sangre derramada por los mártires -y, en especial, aquella de san Lorenzo-, se reafirmaba el sitio de los santos en la liturgia. En tercer lugar, los elementos paganos tenían la función de recordar a los fieles que, si el cristianismo logró vencer al paganismo, sería también capaz de hacer lo propio con los reformistas. Finalmente, estos elementos, como hemos analizado precedentemente, recuerdan la "conquista" de Roma por parte del cristianismo. Esta evocación toma una importancia capital luego de la Reforma protestante, que, a través de los ataques al rol del pontífice y a la jerarquía eclesiástica, había puesto en duda el lugar de la ciudad como caput christianitatis.

Como hemos visto, la tradición iconográfica que consiste en dar una nueva importancia a los dioses y elementos paganos en las representaciones del martirio de san Lorenzo tiene su origen en las obras de Tiziano. Esta innovación iconográfica renovó el contenido simbólico del episodio, a la vez que le proporcionó nuevas claves de lectura. El suplicio del santo fue dotado con referencias tanto a la caída del paganismo como a la supervivencia y a la grandeza del Imperio, que no cedió - como era previsto por las supersticiones paganasante la desaparición del Palladium y la extinción del fuego sagrado. En un segundo momento, la iconografía tizianesca fue retomada por numerosos $\operatorname{artistas}^{70}$, y esta lectura se vio enriquecida por aquella que otorga al episodio un significado complementario, proveyéndolo de un mensaje que objeta las críticas protestantes, evocando la sempiterna lucha de la Iglesia contra la idolatría, la importancia de Roma para la Iglesia y el rol fundamental de los santos, tanto en la cristianización de la ciudad como en la liturgia ${ }^{71}$. La cuestión de la cris-

68 GoldFARB, 2007, p. 98.

69 GoldFarb, 2007, pp. 98-99.

70 Recordemos que las pinturas de Tiziano y la estampa de Cornelis Cort tuvieron una extensa difusión y un recibimiento muy favorable.

71 Podríamos, finalmente, hacer referencia a un tercer y último tiempo en el desarrollo de esta iconografía, que corresponde al momento en que los elementos paganos de las figuraciones del martirio de san Lorenzo se transforman en un topos iconográfico y pierden, progresivamente, su capacidad de evocar los conceptos examinados anteriormente. 
tianización del espacio pagano fue, de esta manera, reactualizada y puesta en el centro de algunas de las controversias propias a la época posterior a la Reforma protestante. Gracias a este procedimiento, los ídolos paganos, "piedras muertas" según San Agustín"2, fueron contrapuestos a los mártires, piedras que sufren y que, muriendo, siguen el ejemplo de Cristo y se transforman en la base del edificio eclesial.

JUAN MAURO BOZZANO, luego de haber hecho estudios en historia del arte en la École du Louvre y en la Universidad Lille III - Charles de Gaulle, ha realizado un Máster de especialización en Renacimiento italiano en la Universidad París 1 - Panteón-Sorbona bajo la dirección de Philippe Morel. Actualmente es doctorando en la Universidad de Alcalá de Henares, y lleva a cabo una tesis titulada "Los elementos paganos en la visualización de la imagen sagrada. Aproximaciones, usos y recepciones, del Quattrocento al Seicento", bajo la dirección de Benito Navarrete Prieto. Email: j.m.bozzano@gmail.com

Código ORCID: https://orcid.org/0000-0001-8656-7638

72 SAn Agustín, Salmos, 96, 11: "se sonrojan los que adoran piedras. Porque aquellas piedras estaban muertas, y nosotros hemos encontrado la piedra viva. Es más, aquellas piedras nunca estuvieron vivas, para que se pueda decir que estaban muertas". 